University of Nebraska - Lincoln

DigitalCommons@University of Nebraska - Lincoln

Faculty Publications from the Harold W. Manter Laboratory of Parasitology

4-26-2001

\title{
Persistent Fontanelles in Rodent Skulls
}

Scott Lyell Gardner

University of Nebraska - Lincoln, slg@unl.edu

Sydney Anderson

American Museum of Natural History

Follow this and additional works at: https://digitalcommons.unl.edu/parasitologyfacpubs

Part of the Parasitology Commons

Gardner, Scott Lyell and Anderson, Sydney, "Persistent Fontanelles in Rodent Skulls" (2001). Faculty Publications from the Harold W. Manter Laboratory of Parasitology. 72.

https://digitalcommons.unl.edu/parasitologyfacpubs/72

This Article is brought to you for free and open access by the Parasitology, Harold W. Manter Laboratory of at DigitalCommons@University of Nebraska - Lincoln. It has been accepted for inclusion in Faculty Publications from the Harold W. Manter Laboratory of Parasitology by an authorized administrator of DigitalCommons@University of Nebraska - Lincoln. 


\title{
NAMERICAN MUSEUM \\ Novitates
}

PUBLISHED BY THE AMERICAN MUSEUM OF NATURAL HISTORY CENTRAL PARK WEST AT 79TH STREET, NEW YORK, NY 10024 Number 3327, 15 pp., 8 figures, 1 table

\section{Persistent Fontanelles in Rodent Skulls}

\author{
SCOTT LYELL GARDNER ${ }^{1}$ AND SYDNEY ANDERSON²
}

\begin{abstract}
Persistent fenestrae occur between frontal or parietal bones in skulls of various rodents, especially species of Andinomys and Ctenomys. The frequency of occurrence and the shape and position of the fenestrae may vary with age or among individuals, populations, and species. Different families and species from both high and low elevations exhibit fenestrae. They have arisen in several different evolutionary lineages. Genetic factors contribute, but no clear functional significance of the fenestrae has been established.
\end{abstract}

\section{INTRODUCTION}

Several years ago we noticed openings in the dorsal surface of various rodent skulls that we were collecting in Bolivia, usually between the frontals and/or parietals, specifically in Andinomys edax, a murid, and in more than one species of Ctenomys (fig. 1), a caviomorph genus, from both the altiplano and the lowland regions of Bolivia.

Persistent fenestrae in fontanelle sites (openings that remain at an age when the openings in embryonic or infant braincases between bones have closed in most other mammals) or nearby sutures of rodent skulls have been noticed by a few workers over the years. These fenestrae occur in fewer taxonomic groups than do extra ossifications in these sites.

We focus on the species of the genus Ctenomys and on Bolivia. Selected material beyond this genus (phyllotines, octodontids, caviids) is included for comparison. The emphasis on Bolivia is for the pragmatic reason that we were examining thousands of specimens for a faunal study (Anderson, 1997). Our goal here is to conduct a broad taxonomic survey of midsagittal cranial fenestrae in Bolivian rodents.

We note that the presence of these fenestrae was not noted by Hinton (1926) in his

\footnotetext{
${ }^{1}$ Curator of Parasitology, Harold W. Manter Laboratory of Parasitology, University of Nebraska-Lincoln, Lincoln, NE 68588-0514.

${ }^{2}$ Curator Emeritus, Division of Vertebrate Zoology (Mammalogy), American Museum of Natural History.
} 
classic book on the microtine rodents nor have we found it in later reviews of the Rodentia in general or in works dealing with cranial foramina in rodents (e.g., Hill, 1935; Wahlert et al., 1993).

\section{INSTITUTIONAL ABBREVIATIONS}

AMNH American Museum of Natural History BM British Museum (Natural History), now "The Natural History Museum", London

CBF Colección Boliviana de Fauna, La Paz

MNK Museo de Historia Natural "Noel Kempff Mercado', Santa Cruz de la Sierra, Bolivia

MSB Museum of Southwestern Biology, University of New Mexico, Albuquerque

MVZ Museum of Verebrate Zoology, University of California, Berkeley

MNHN Muséum National d'Histoire Naturelle, Paris

Authors, authorities, dates, and references to sources of the scientific names used here may be found in Wilson and Reeder (1993), Anderson (1997), or Cook et al. (1990: 11).

Data on Ctenomys are summarized in table I. We considered a table for other groups but decided that too many items needed qualification. The great variability in size, shape, and position of fenestrae convinced us that it was best to illustrate most individuals possessing the trait from various samples rather than trying to represent the variation by statistics for measurements or just selected extreme conditions or "typical" individuals. Museum catalog numbers are given when we think a future worker will need to examine the individual referred to. In other cases, collection locality and total number in the sample will suffice to remove ambiguity.

Statistical analyses were conducted using Systat 8.0. The interactions between prevalence and altitude were analyzed using the ANOVA function. Correlation coefficients were generated using standard regression equations. Levels of statistical significance were set prior to all analyses at $\mathrm{p} \leq 0.05$.

\section{RESULTS}

\section{Muridae, Sigmodontinae, Phyllotini}

Andinomys edax.-Osgood (1947: 173) wrote that "in ten skulls examined there is a slit-like opening between the frontals at the center of the interorbital region." Hershkovitz (1962: 475) showed photographs of two skulls of Andinomys with frontal fontanelles and wrote (p. 474) "A slit-like fontanelle sometimes present between anterior halves of frontals. A second fontanelle sometimes present between posterior ends of frontals." Also (p. 476), "the interfrontal fontanelles are larger and more consistently present in Andinomys than in other cricetines," and (p. 477) "Interfrontal fontanelles occur sporadically in a number of cricetines." Incomplete fusion or apparent vascularization along the midline was noted in Andinomys and Irenomys by Steppan (1995: 33, 70, 92, 93). He noted (p. 33) that "more than $90 \%$ of Andinomys individuals examined $(\approx 50)$ possess a fontanelle, and several have a second fontanelle in the posterior region of the frontals as well." Twenty-seven specimens were in the list of specimens examined (p. 106). To orient the reader, figure 1 shows the arrangement of the bones in question in a complete skull (fig. 1A) and a reduced drawing (fig. 1B) of the frontals, fenestra or fontanelle, and parietals. The medial frontal sutures in four skulls of Andinomys are illustrated in figure 2. A slit-like fenestra, as noted by Osgood and Hershkovitz, is present in three skulls. In the fourth skull there is no appreciable gap but the bones are unfused in four places.

Auliscomys (Loxodontomys, Maresomys).--Hershkovitz (1962: 477) noted that interfrontal fontanelles "are common, though rarely well developed, in Phyllotis micropus" [now placed in Auliscomys, e.g., Wilson and Reeder (1993:695), or Loxodontomys, e.g., Steppan (1995: 106)]. We examined 14 A. micropus, 24 A. pictus, 61 A. sublimis, and six A. boliviensis (the latter placed in the genus Maresomys by Braun, 1993). Only one skull has a fenestra (fig. 2, A. micropus, AMNH 14290, from Rio Chico, Santa Cruz, Argentina).

Galenomys garleppi.-None of the eight skulls examined has an open fenestra.

Tapecomys primus.-Two skulls of this phyllotine, from Tapecua, Tarija Department, Bolivia (CBF 2414 and AMNH 264448) do not exhibit any sagittal fenestrae.

A skull of Punomys lemminus from Peru, 


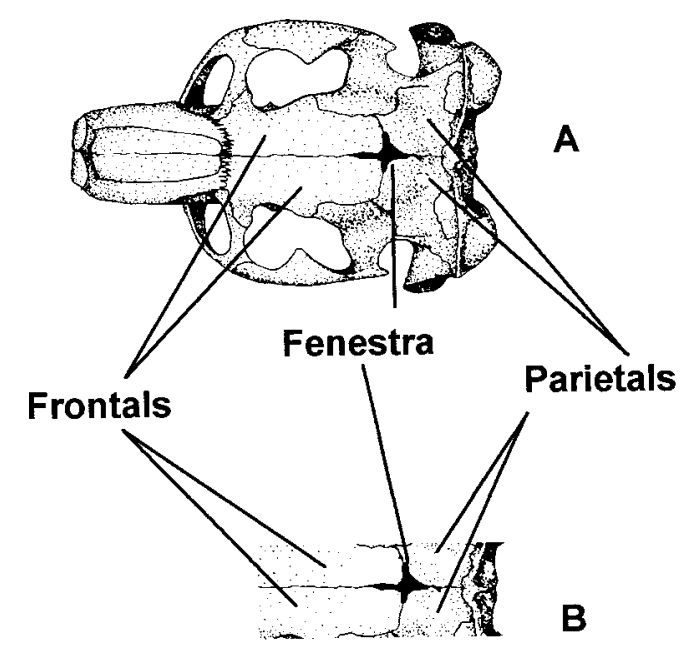

Fig. 1. A. Drawing of skull of Ctenomys sp., dorsal aspect with fenestra evident at junction of frontal and parietal bones. B. Dorsal aspect of only frontals and parietals showing relative relationship of bones as in figures 2-7.

figured by Pacheco and Patton (1995:89), shows a slit-like opening between the frontals in the region of the interorbital constriction. Steppan (1995: 16) studied 12 specimens of P. lemminus and scored Punomys as having "partially open or vascularized" mediodorsal frontal sutures but no further details were provided. Punomys was assigned to Phyllotini by Olds and Anderson (1990: 63), but Steppan (1995: 109) placed it incertae sedis in Sigmodontinae.

Neotomys ebriosus.-Hershkovitz (1962: 477) noted that interfrontal fontanelles are "nearly as prevalent in the sigmodont rednosed vole Neotomys as in Andinomys." Steppan (1995: 32, 97) published a photograph of a Peruvian skull with a small midfrontal slit. None of 10 Bolivian skulls (AMNH) of Neotomys showed an opening, but the middle part of the sagittal suture between the frontal bones is not tightly fused in four. A few of the 43 Peruvian skulls examined have a complete and unambiguous meeting of the frontal bones throughout their midsagittal length, but most do not. In most skulls and usually in the posterior part of the suture, there are areas where fusion has not occurred or actual gaps appear (fig. 2). If all connective tissues have been removed from the area in cleaning the skull, another layer of bone is usually visible through the gap. There is a thickening of the bone near the midsagittal line and often a shallow space within this thickening. Whether this is a sinus or is occupied by a blood vessel or other tissue is not clear in the cleaned skulls. In a few cases, the opening is not underlain by other bone and extends into the braincase. For example, in specimen AMNH 231634 the anterior gap is completely open and the posterior gaps exhibit bone beneath them.

\section{OCTODONTIDAE}

Aconaemys fuscus.-Three (young adults) of 13 skulls (11 MVZ, 2 AMNH) from Argentina have fenestrae. One (MVZ 163418) has a fenestra 2.1 by $0.5 \mathrm{~mm}$, one (AMNH 91654 ) is 2.5 by $0.3 \mathrm{~mm}$, and one (AMNH $91655)$ is 4 by $1 \mathrm{~mm}$. Two other young individuals lack fenestrae.

Octodon degus.-One (MVZ 150081, a juvenile) of 21 skulls (5 AMNH, reared in the laboratory; and $16 \mathrm{MVZ}$, from $1000 \mathrm{~m}$ elevation in Chile) had a minute fenestra (2 by $0.5 \mathrm{~mm}$ ).

Octodon lunatus.-Two of 24 skulls (5 AMNH, 19 MVZ) had a fenestra. These two animals were young, and the fenestrae were along the midsagittal line (AMNH 33275, 40075, 2 by $4 \mathrm{~mm}$ ). All MVZ specimens (from $1000 \mathrm{~m}$ in Chile) were adults and none had fenestrae.

Octodontomys gliroides.-Six skulls (AMNH 249050-249054, 249057) from Caracato, $2900 \mathrm{~m}$, were examined. The three largest skulls had no fenestrae. The three smallest (and presumably the youngest) have partly unfused sutures between the frontals and in two cases also between frontals and parietals. One has a distinct fenestra (AMNH 249057), the other two have noticeable gaps along the sutures. In this case the fenestrae seem to close with age.

Spalacopus cyanus.-Two of seven skulls from Chile had fenestrae. A juvenile (MVZ 150112) had a fenestra 2.8 (anteroposteriorly) by $3.4 \mathrm{~mm}$. Another juvenile (AMNH 33276) has a sagittal fenestra (3.0 by 0.5 $\mathrm{mm})$. The greatest width is at the transverse suture and the suture anterior to the fenestra is open for another $3 \mathrm{~mm}$. 

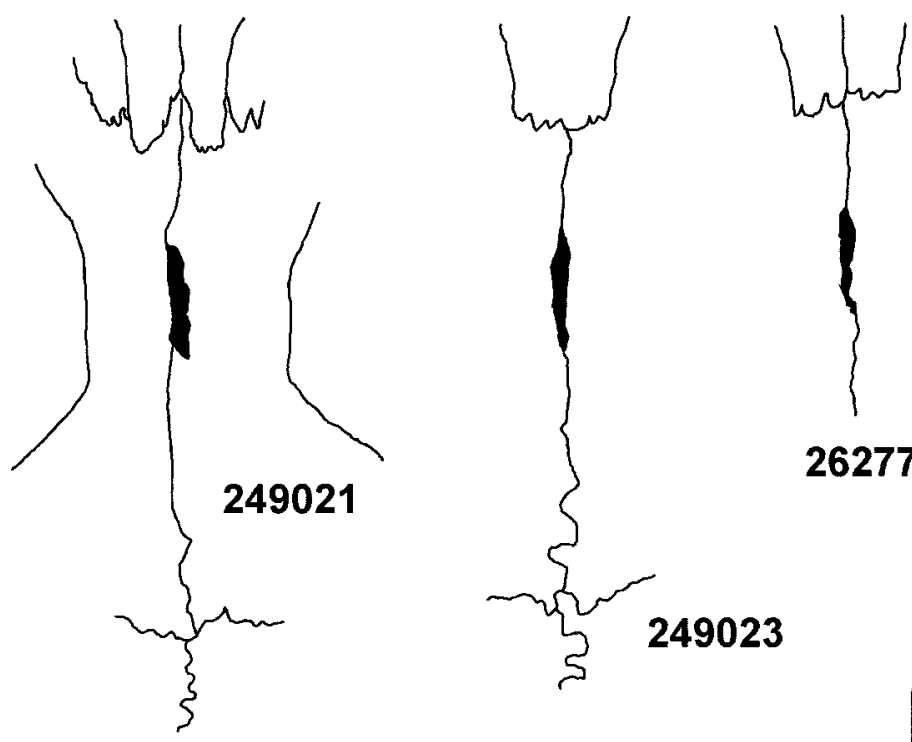

262770

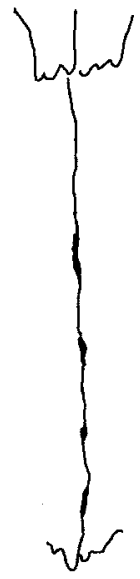

249022

\section{Andinomys edax}

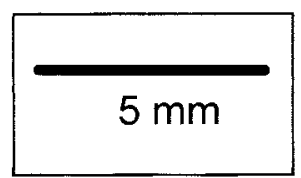

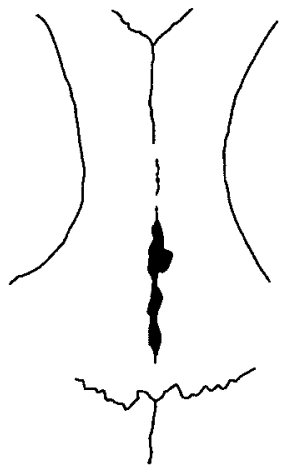

231732
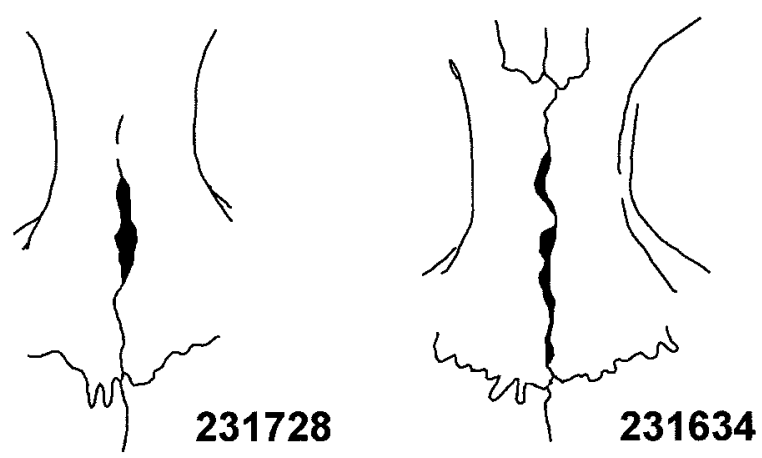

\section{Neotomys ebriosus}

Fig. 2. Drawings of interorbital area of skull in Andinomys edax (four specimens at AMNH).

\section{CTENOMYidae}

Ctenomys boliviensis.-One (AMNH 260830, in fig. 3) skull has a narrow and convoluted transverse fenestra and also a tiny opening about $4 \mathrm{~mm}$ anterior to this. Most (306 of 375 , or $81 \%$ ) of the skulls lack fenestrae. Of the 69 with fenestrae, the maximum length (anteroposterior) is $4.48 \mathrm{~mm}$ (MSB 59452) and the maximum width (transversely) is $5.35 \mathrm{~mm}$ (MSB 59410). In a sample of 52 with the relevant measurements, the fenestra of 13 is more than twice as long (anteroposteriorly) as wide, in 8 it is more than twice as wide (transversely) as "long" (anteroposteriorly), and 31 fell between these extremes. Considerable variation in shape is thus evident.

Ctenomys boliviensis nattereri.-In one skull from Mato Grosso in Brazil a small slit-like opening is present, as is a small 
opening at the back of the parietal where two interparietal (bregmatic) ossifications appear. This taxon was treated as a full species, $C$. nattereri, in Wilson and Reeder (1993: 786).

Ctenomys conoveri.-One skull has a fenestra $6 \mathrm{~mm}$ long (fig. 3, shown also in a cranial photo by Anderson et al., 1987: 10). Another skull lacks fenestra.

Ctenomys frater.-Fenestrae were illustrated in cranial photos of C. f. mordosus (AMNH 263011) and C. f. frater (BM 2.2.2.112) by Cook et al. (1990: 11). Unusual bilateral fenestrae were present in one case (AMNH 263013) and nasal fenestrae, similar to those seen in one $C$. minutus, were present in one skull (AMNH 263011) (fig. 7). One skull (AMNH 263014) had no fenestra. Two of three other specimens (MSB 57188, 57191) exhibit fenestrae.

Ctenomys fulvus.-None of four skulls (MVZ) from $4310 \mathrm{~m}$ in Chile has a fenestra.

Ctenomys goodfellowi.-Formerly considered to be a subspecies of $C$. boliviensis. Recognized as a separate species by Anderson (1997: 495). Skulls of specimens from 2 km SE of Santa Rosa de la Roca (3, AMNH 263920; MSB 63379, 63380) and $10 \mathrm{~km} \mathrm{~N}$ of San Ramón (3, AMNH 262288, 262289; MSB 56087) have no fenestrae.

Ctenomys haigi.-Fenestrae were present in nine of 16 skulls (MVZ) from Argentina.

Ctenomys leucodon.-None of the eight skulls examined (2 at MSB, 3 at MVZ, and 3 AMNH), from the highlands of Bolivia, has a fenestra.

Ctenomys lewisi.-Fenestrae in the transverse parietal suture are illustrated for two specimens (fig. 3), both are young. Each of two others (AMNH 264542 and 264546) has a minute fenestra. Eight others have none.

Ctenomys magellanicus.-One skull (MNHN 832) of six from Argentina (4 AMNH, $1 \mathrm{MVZ}, 1 \mathrm{MNHN}$ ) has a fenestra. Ctenomys maulinus.-Six of 12 skulls from Argentina (3 AMNH, 9 MVZ) have fenestrae.

Ctenomys minutus. - As noted above, one skull from eastern Bolivia, (AMNH 260835) has two unusual nasal fenestrae (fig. 3, and in a cranial photo in Anderson et al., 1987: 8 ) but none in the midfrontal or parietal ar- eas. Another specimen (MSB 55367) also lacked a fenestra.

Ctenomys opimus.-Fenestrae occur in 44 of 54 skulls (AMNH 21, MSB 14, MVZ 19). Fenestrae in 20 skulls (AMNH) are shown in figure 3 . Of the 44 with measurements of fenestrae, the maximum length is $9.02 \mathrm{~mm}$ (MSB 55374) and the maximum width (transversely) is $3.7 \mathrm{~mm}$ (AMNH 263040). The fenestra of 37 was more than twice as long (anteroposteriorly) as wide, in none was it more than twice as wide (transversely) as long (anteroposteriorly), and 7 fell between these extremes. In this sample, there were no statistical differences in mean sizes (lengths or widths) of fenestrae between males and females.

Ctenomys pearsoni.-Four of 35 skulls from Uruguay have loose sutures, in whole or in part, between the parietals, but no gap, one has a gap at the back, one has a small fenestra at the front, and one has an opening on the transverse suture between frontal and parietal and about $3 \mathrm{~mm}$ to the right of the midline.

Ctenomys rionegrensis.-One skull from Uruguay has a small fenestra. Originally named as a subspecies, Ctenomys minutus rionegrensis, by Langguth and Abella (1970: 13), but subsequently treated as a distinct species by some authors (e.g., Altuna and Lessa, 1985: 483).

Ctenomys steinbachi.-Most (36 of 41) skulls from Bolivia do not have fenestrae (3 with fenestrae are shown in fig. 3). In two there is a transverse fenestra along the suture between the frontal and parietal bones. One skull has two tiny gaps about $3 \mathrm{~mm}$ behind this suture and between the parietal bones. Two not figured are minute (1.06 and 1.54 $\mathrm{mm}$ in length).

Ctenomys torquatus. - No fenestrae were observed in eight skulls from southern Brazil. Only six of 57 skulls from Uruguay have fenestrae, five of these are tiny, one is sizeable. In five other skulls at least part of the interparietal suture is unfused but there is no gap. One of the tiny openings is at the back of the parietal bone rather than in the usual position at the front of this bone, one skull has a loose transverse suture with a small gap between frontal and parietal bones.

Ctenomys tucumanus.-One of three 


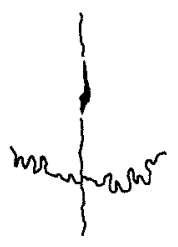

263051
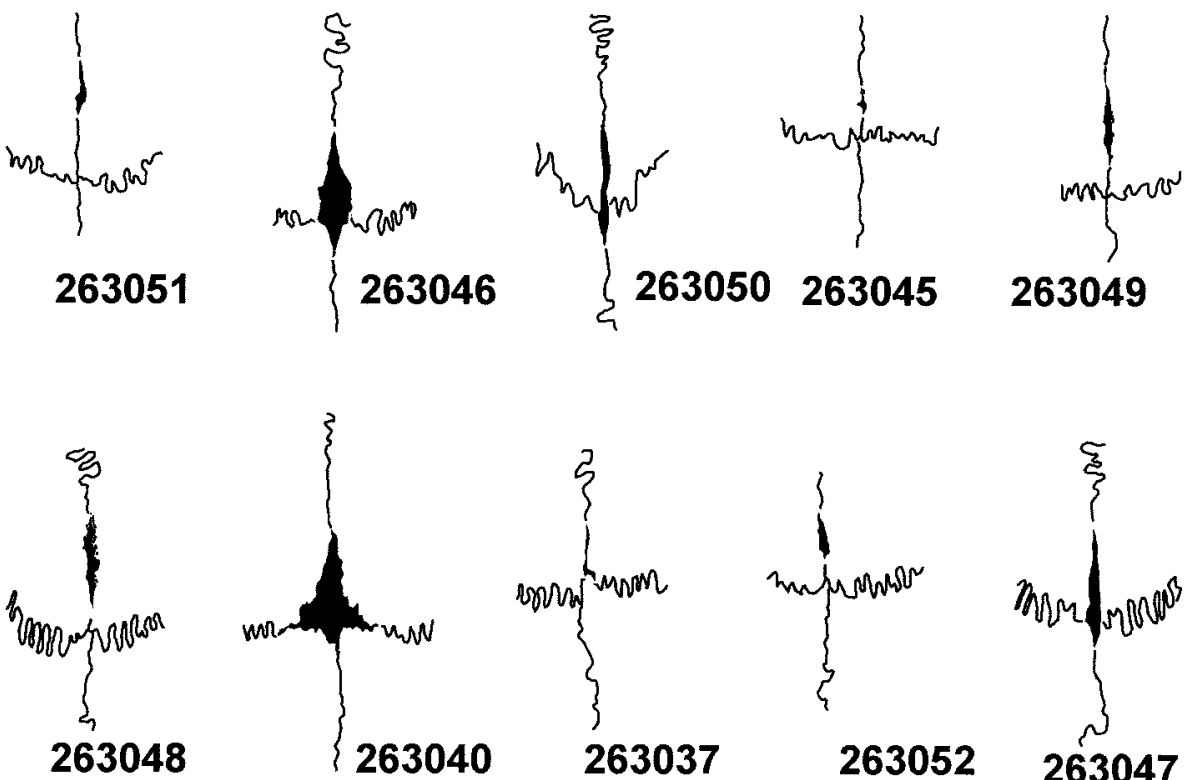

263048
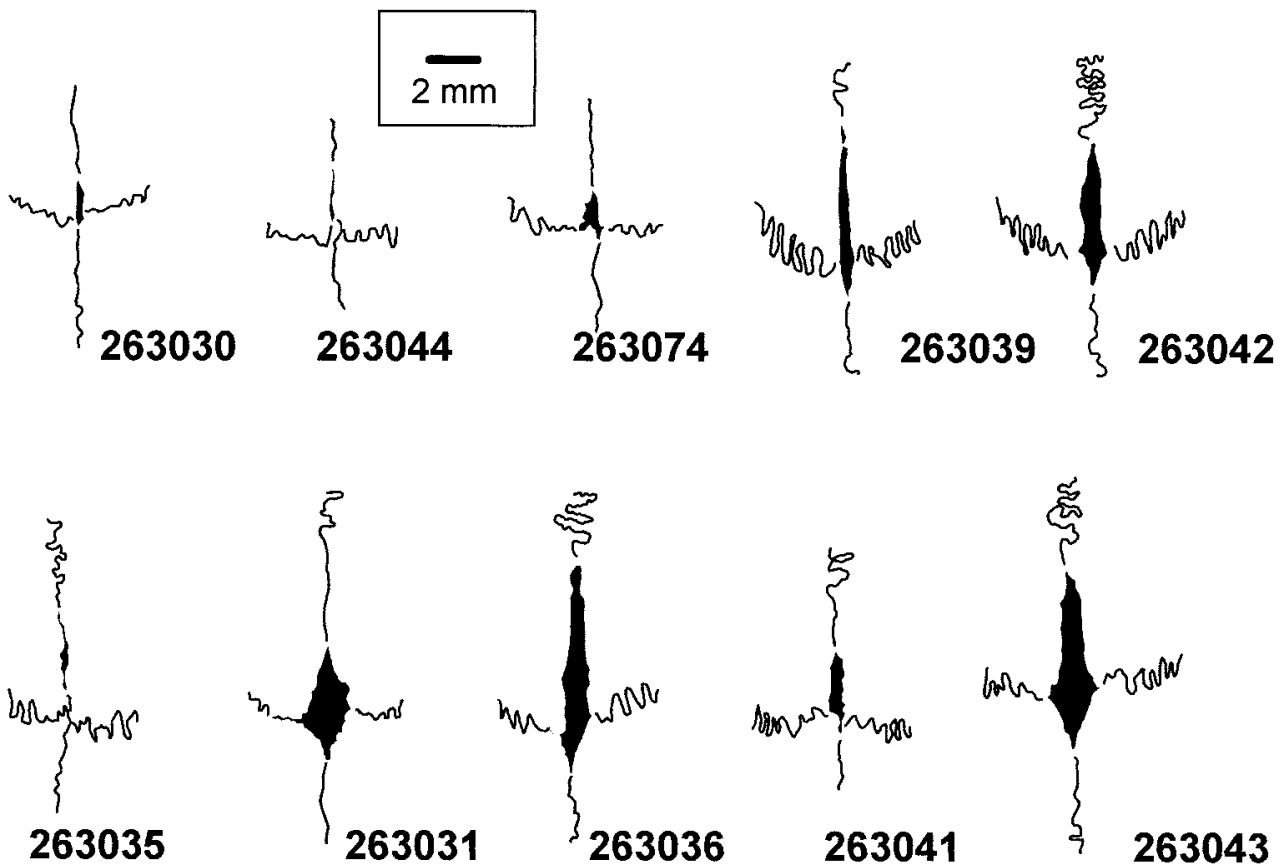

\section{Ctenomys opimus}

Fig. 3. Frontoparietal area of 20 specimens of Ctenomys opimus. 

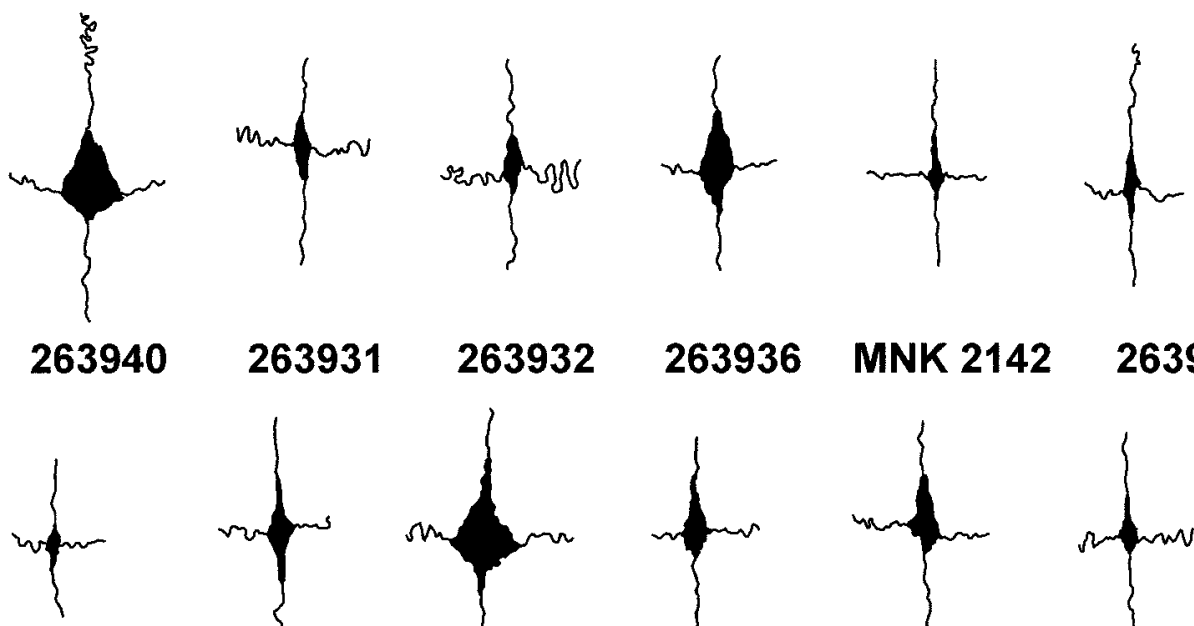

263931

263932

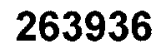

MNK 2142

263938
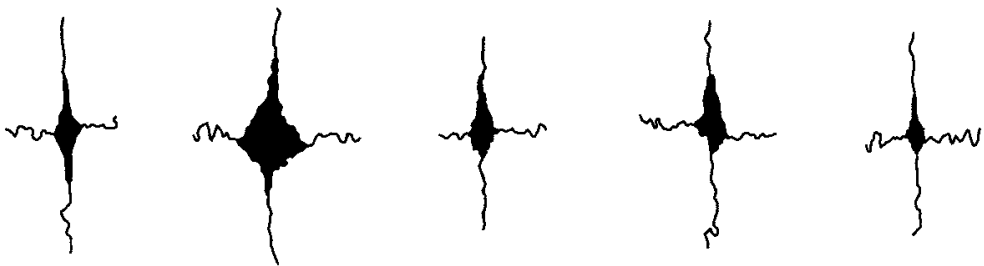

263941263939

MNK585

MNK 622

MNK 625

263933

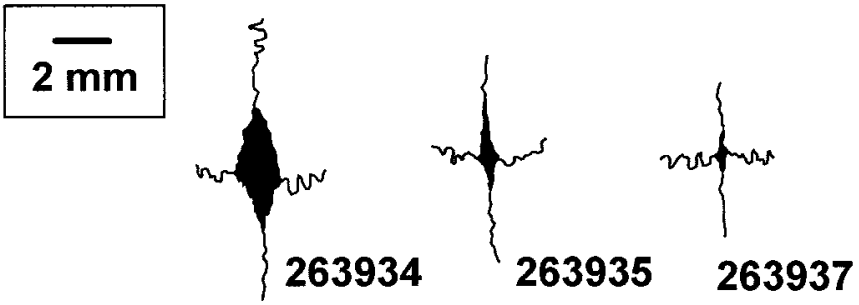

\section{Ctenomys sp.}

\section{Cerro Itahuaticua}

Fig. 4. Frontoparietal area of 15 specimens of Ctenomys, not yet identified to species, from Cerro Itahuaticua.

skulls (MNHN) from Argentina had a fenestra $(1.0$ by $0.6 \mathrm{~mm})$.

Ctenomys, Roboré sample.-Specimens from near Roboré in eastern Santa Cruz are now considered to be a species separate from C. boliviensis, to which they were formerly referred. Neither of two skulls examined has a foramina.

Several new series, treated below, have been obtained from the region along the eastern edge of the Altiplano highlands. These localities are between the previously known ranges of Bolivian species of Ctenomys. These samples differ from all the previously known taxa and their taxonomic status is still under study. Localities or catalog numbers will provide unambiguous identifications, when the revision is published.

Ctenomys, Itahuaticua sample.-Two of 22 skulls from near Cerro Itahuaticua in southern Santa Cruz Department, Bolivia, lack a fenestra, 20 have fenestrae ranging from less than 2 to $5 \mathrm{~mm}$ in anteroposterior length and from about 0.5 to $3 \mathrm{~mm}$ in width. The openings are roughly symmetrical bilaterally and in 17 of 20 cases extend slightly farther anterior to the transverse suture than posterior to it (fig. 4).

Ctenomys, Monteagudo sample.-Five of 23 skulls from near Monteagudo, in Chu- 
quisaca Department, Bolivia, have no fenestrae, 15 have relatively small fenestrae (i.e., from less than 0.5 to $3.6 \mathrm{~mm}$ in anteroposterior length and from less than 0.5 to 2.5 $\mathrm{mm}$ in width), and 13 extend anteriorly farther than posteriorly from the transverse frontoparietal suture (fig. 6).

Ctenomys, Chuhuayaco sample.-All but one of 13 skulls from near Chuhuayaco, in Chuquisaca Department, Bolivia, have fenestrae and these are more variable than in most other species of Ctenomys. The anteroposterior dimension ( 1.2 to $4.5 \mathrm{~mm})$, is greater than the lateral dimension $(0.5$ to $3.0 \mathrm{~mm})$ in all but one skull, in which the transverse fenestra is $3 \mathrm{~mm}$ in its lateral dimension. The posterior border of one fenestra is about 1.5 $\mathrm{mm}$ anterior to the transverse suture, all other fenestrae are at the suture, and eight of these extend farther anterior than posterior to the transverse suture (fig. 6).

Ctenomys, Tapecua sample.-The one specimen examined from Tapecua in Tarija has a foramen (fig. 7).

Ctenomys, Vallegrande sample.-Eleven specimens (AMNH 264548-264555, MSB $67362,67104,67105)$ from $5 \mathrm{~km}$ NNE of Vallegrande have fenestrae of various sizes, all at or near the junction of the frontal and parietal sutures (fig. 7).

Ctenomys, Lluthu Pampa sample.-Five skulls (AMNH 264557-264560, MSB 67112) from $0.5 \mathrm{~km} \mathrm{~N}$ of Lluthu Pampa in Cochabamba have narrow longitudinal fenestrae (fig. 7).

\section{CAviIDae}

Examination of a number of Caviidae (15 skulls of Cavia, 67 of Galea, 11 of Microcavia, and 14 of Dolichotis) revealed one young Cavia with the fontanelle unclosed and one young Microcavia niata niata (fig. 3, AMNH 246953, from near Eucaliptus in northern Oruro Department, Bolivia) with a slitlike opening.

\section{DISCUSSION}

Other occasional variations in the midsagittal and dorsal part of the skull have been reported, namely the occurrence of extra small ossifications (bregmatic bones). For example, Manville (1959: 1254) wrote that "these accessory, sutural bones, which form only in occasional cases, develop from one or more ossification centers in the membrane which closes the anterior fontanelle in fetal life. In the bobcat, they may be large or small in size, central or lateral in position, single or multiple in number, and they are almost always asymmetrical in shape." Extra ossifications of this type are rare in rodents. Supernumery bones bordering the parietal and/ or interparietal were reported by Genoways (1973: 40) in 16 individuals of Liomys pictus (of 950 examined). "Interfrontal" bones were reported by Truslove (1952: 116) to occur commonly in two strains of Mus musculus. Truslove (p. 118) noted that "In none of the stocks is there any evidence for a parent-offspring correlation. Hence it must be concluded that each of the three stocks ... breeds true to the production of its own characteristic incidence of interfrontal. Within each stock, presence or absence of the bone is thus determined by the environment; as the interfrontal is present at birth, the decision must have occurred during embryonic life." Truslove (1952: 119) also described "parted frontals" in several strains of Mus musculus. Berry and Searle (1963: 578) discussed the genetic and evolutionary aspects of "epigenetic" polymorphism. They considered 55 examples, including "parted frontals", "frontal fontanelle", and "interfrontal present". They examined specimens of 10 species of rodents but added only one Rattus norvegicus skull with a fontanelle between the parietals to the examples of parted frontals and frontal fontanelle cited earlier by Truslove (1952). Interfrontal bones were observed in $6 \%$ of 24 Cavia porcellus examined. Probably such bones occur in orders of mammals other than the Primates, Carnivora, and Rodentia here documented. A bregmatic bone in a gibbon, Hylobates, was reported by Soria (1962), bregmatic bones in Lynx were reported by Pratt (1942).

Scattered references in the medical literature attest to the occurrence of fontanelle bones (same as bregmatic bones) in humans and to variation in the size of fontanelles and their times of closure. Bones in the anterior fontanelle and its contiguous sutures are regarded as normal and relatively common variants that do not interfere with normal 

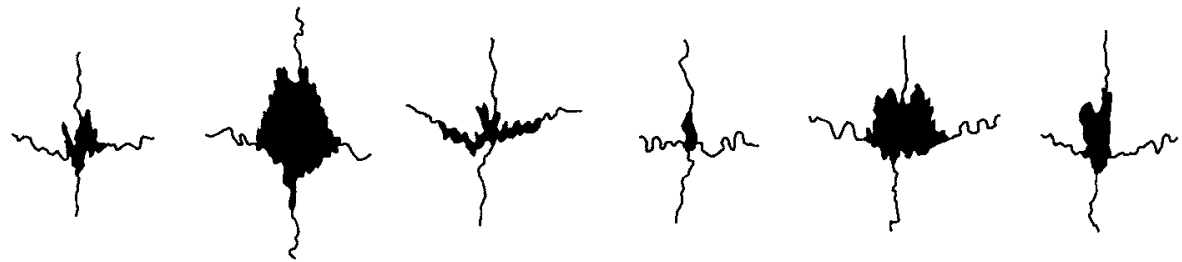

2639521105 CBF 1164 CBF 263927

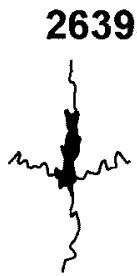

263922
263929

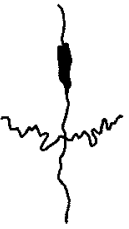

$1102 \mathrm{CBF}$

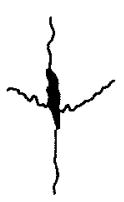

MSB 633941160 CBF

Ctenomys sp.
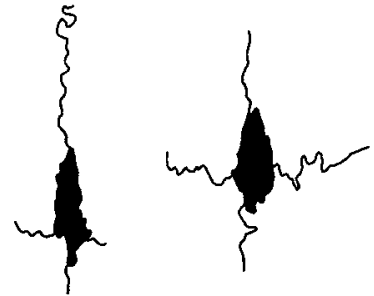

1182 CBF<smiles>CC=C(C)C(=O)O</smiles><smiles>CC(C)(C)C1CCCCC1</smiles>

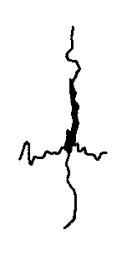
Chuhuayuco

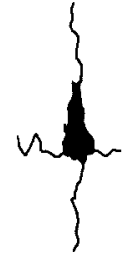<smiles>CC(C)C(C)C(C)C</smiles><smiles>CCC(C)C(C)C(C)C</smiles>

$2639441109 \mathrm{CBF}$ 2654 CBF

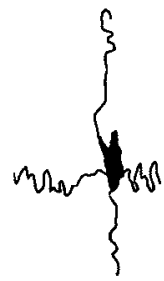<smiles>CC(C)(I)C(I)(I)I</smiles><smiles>CC(C)(C)C(C)(C)C</smiles><smiles>CCC(C)(C)C</smiles>

$263946 \quad 263943$

\section{3}

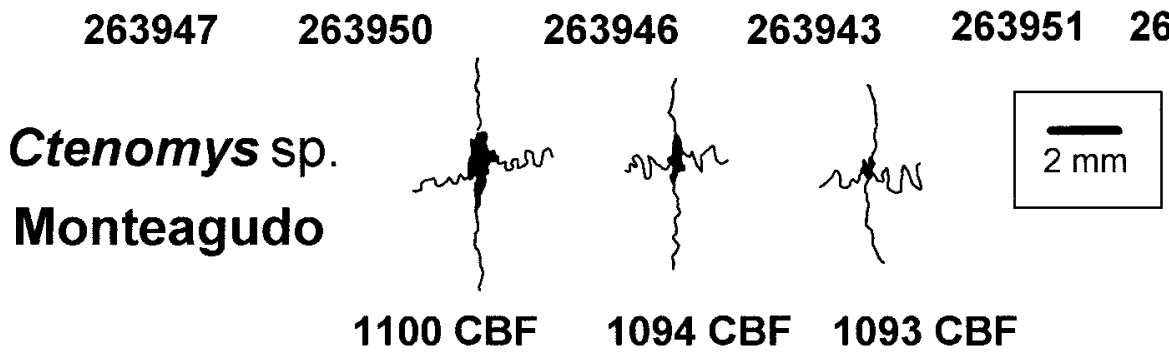

Fig. 5. Frontoparietal area of specimens of two different series of Ctenomys, not yet identified to species, 11 from near Chuhuayaco and 15 from near Monteagudo. 

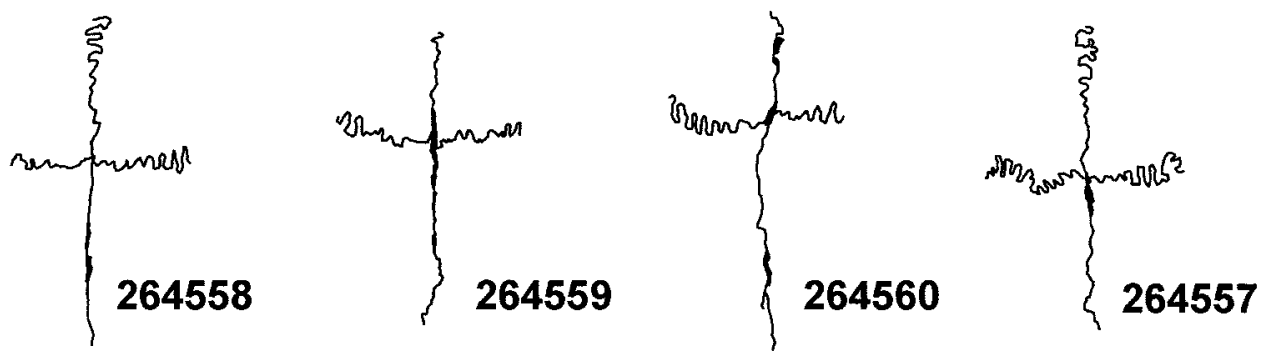

\section{Ctenomys sp. Lluthu pampa}
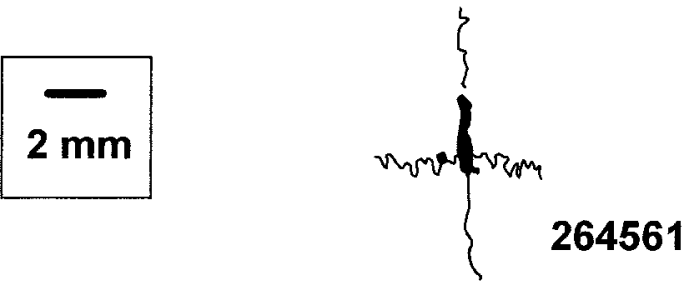

\section{Ctenomys sp. Tapecua}
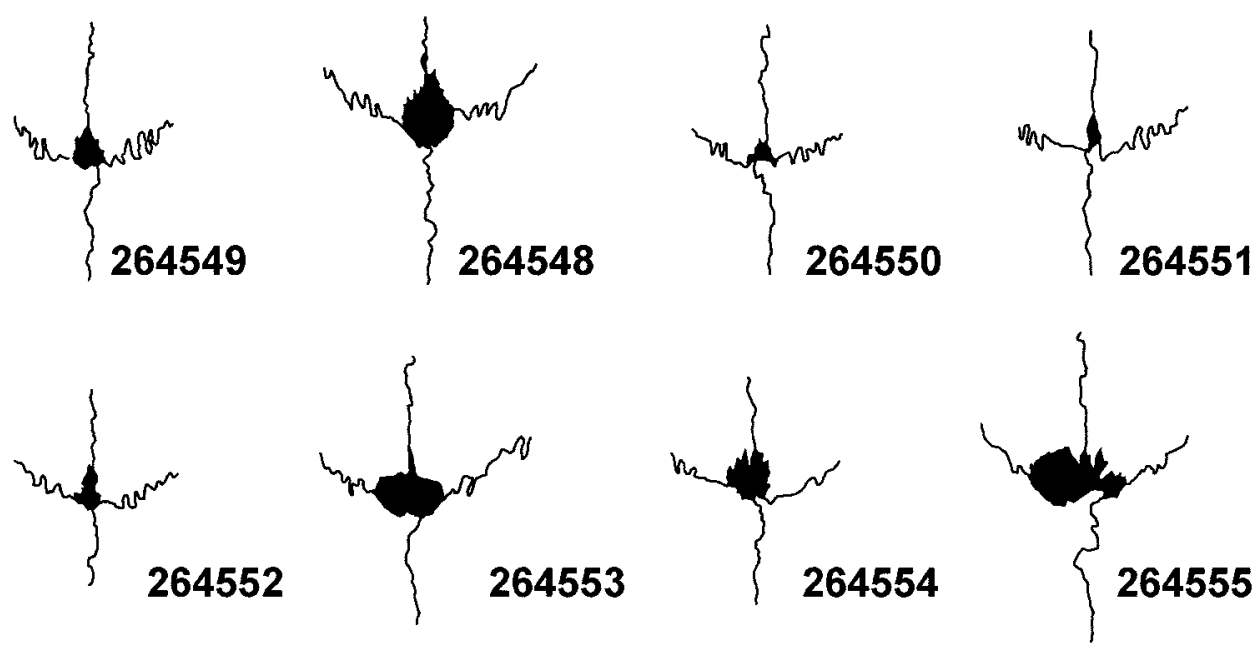

\section{Ctenomys sp. Vallegrande}

Fig. 6. Frontoparietal area of specimens of three samples of Ctenomys (1 skull from Tapecua, 4 from near Lluthu Pampa, and 8 from near Vallegrande).

growth of the skull (Girdany and Blank, 1965). They are usually single and fusion with surrounding bones usually occurs before the fifth year. Fontanelle bones were seen in about $11 \%$ of 3522 human skulls (Kadanoff and Mutafov, 1963). In a study of 111 term and 128 preterm infants, great variability of size and age when closure oc- 

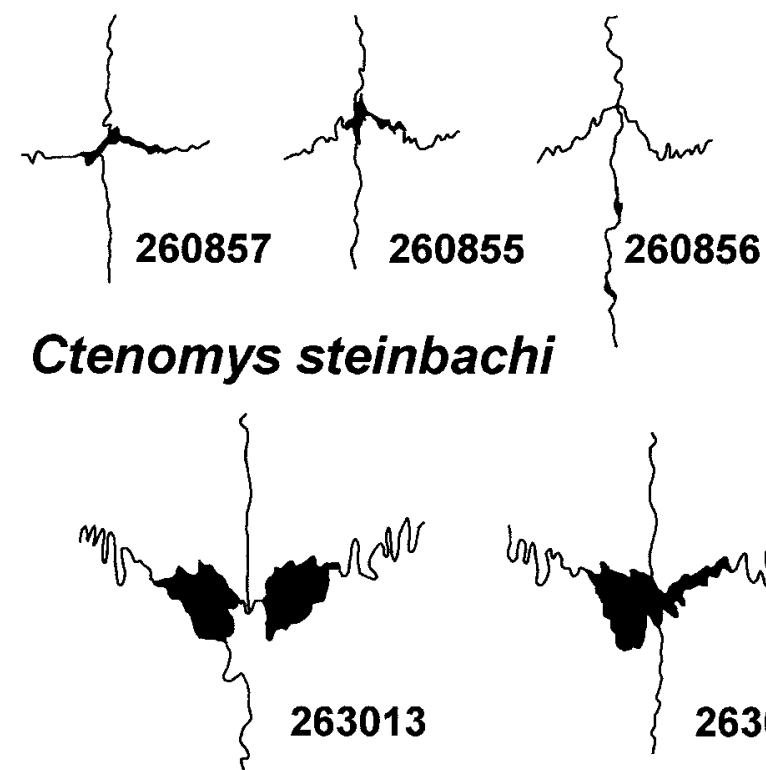

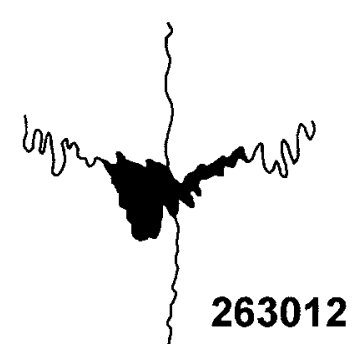

Ctenomys boliviensis

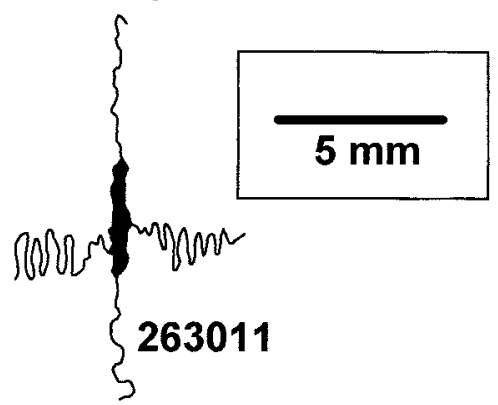

Ctenomys frater

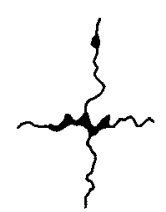

260830

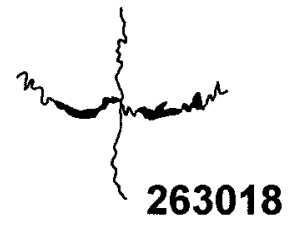

Ctenomys lewisi

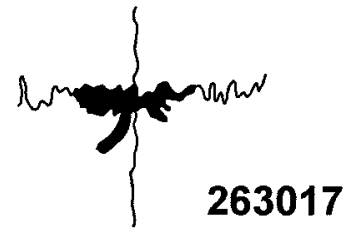

263017

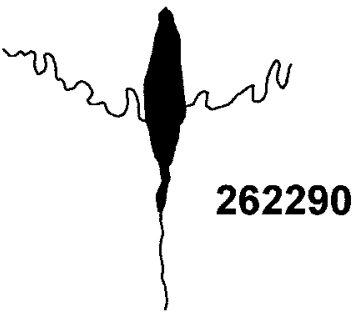

Ctenomys conoveri
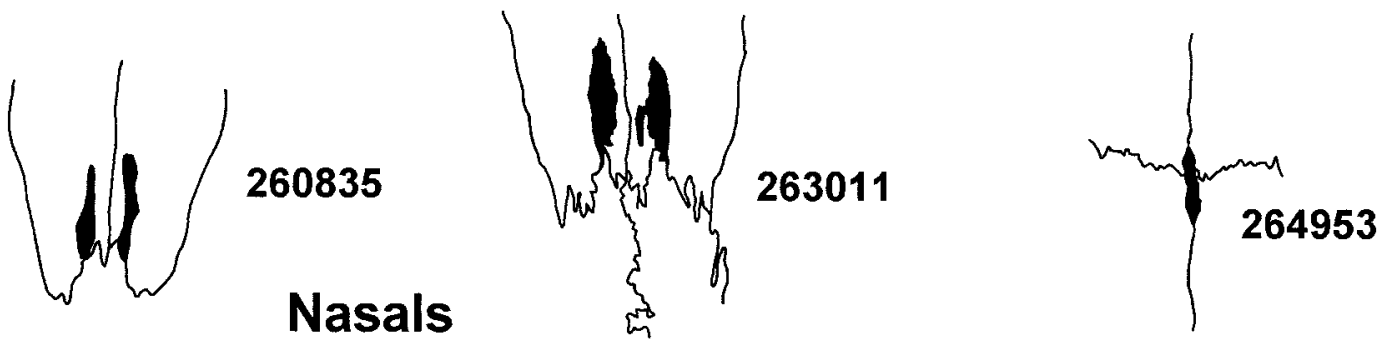

\section{Ctenomys minutus Ctenomys frater Microcavia niata}

Fig. 7. Drawings of frontoparietal area showing intersection of transverse parieto-frontal suture and midsagittal suture of skull in five species of Ctenomys and in Microcavia niata. Fenestrae in the nasal bones of one specimen of Ctenomys minutus and one of $C$. frater mordosus are also illustrated. 
TABLE 1

Prevalence of Fenestrae in Ctenomys (from Bolivia, except where noted otherwise)

\begin{tabular}{|c|c|c|c|}
\hline Species & No. examined & No. (and \%) with fenestrae & Elev., $\mathrm{m}$ \\
\hline C. boliviensis & 375 & $69(19)$ & 510 \\
\hline C. conoveri & 2 & $1(50)$ & 500 \\
\hline C. frater & 4 & $3(75)$ & 2100 \\
\hline C. fulvus (Chile) & 4 & $0(0)$ & 4310 \\
\hline C. goodfellowi & 6 & $0(0)$ & 510 \\
\hline C. haigi (Argentina) & 16 & $9(56)$ & $500-4100$ \\
\hline C. leucodon & 8 & $0(0)$ & 3800 \\
\hline C. lewisi & 12 & $4(33)$ & 3400 \\
\hline C. magellanicus (Argentina) & 6 & $1(17)$ & - \\
\hline C. maulinus (Argentina) & 12 & $6(50)$ & $1000-2100$ \\
\hline C. minutus & 2 & $0(0)$ & 550 \\
\hline C. optimus & 54 & $44(80)$ & $3500-4000$ \\
\hline C. pearsoni (Uruguay) & 35 & $3(9)$ & $<250$ \\
\hline C. rionegrensis (Uruguay) & 1 & $1(100)$ & $<250$ \\
\hline \multicolumn{4}{|l|}{ C. sp? } \\
\hline Chuhuayaco sample & 13 & $12(92)$ & 2000 \\
\hline Itahuaticua sample & 22 & $20(91)$ & 1500 \\
\hline Lluthu Pampa sample & 6 & $5(83)$ & 2500 \\
\hline Monteagudo sample & 23 & $18(78)$ & 2000 \\
\hline Roboré sample & 2 & $0(0)$ & 300 \\
\hline Tapecua sample & 1 & $1(100)$ & 1500 \\
\hline Vallegrande sample & 11 & $11(100)$ & 1800 \\
\hline C. steinbachi & 41 & $5(12)$ & 510 \\
\hline \multirow{2}{*}{$\begin{array}{l}\text { C. torquatus (Brazil) } \\
\text { (Uruguay) }\end{array}$} & 8 & $0(0)$ & - \\
\hline & 57 & $6(11)$ & $<250$ \\
\hline C. tucumanus (Argentina) & 3 & $1(33)$ & - \\
\hline
\end{tabular}

curred was observed (Duc and Largo, 1986). There was no significant difference between the two groups or between the sexes. After birth, the fontanelle gradually closes and its size negatively correlates with the weight and length of the infant, but the age at final closure of the fontanelle was not significantly related to any growth parameter. In other words, the rate of closure is variable among individuals.

Rausch et al. (1987) specifically discussed the occurrence, possible origin, and significance of such interfrontal fenestrae in lemmings of the genus Dicrostonyx. They noted that the fenestra was "typically elongate, somewhat spindle-shaped, and bilaterally symmetrical, was covered dorsally by skin and periosteum; ventral to it, between the periosteal and meningeal layers of the dura mater, lay the superior sagittal sinus." They described the fenestra in lemmings at the age of 8 days and noted that it did not tend to close further with increasing age. They postulated that "its inheritance involves a dominant autosomal gene with incomplete penetrance." They wrote that "the functional significance of the fenestration is unknown" and noted that "its frequency tends to increase with latitude, approaching $100 \%$ near the northern limits of the range of Dicrostonyx spp." Some possible role in pineal function by which seasonal reproduction of lemmings is influenced was suggested. The direct accessibility of the sagittal sinus and underlying cerebral tissue in a rodent that reproduces well in the laboratory was noted as a practical consideration. However, we know of no later study taking advantage of this accessibility.

While studying the mammalian fauna of Bolivia, we examined many specimens of various phyllotine genera, including Phyllotis, Graomys, Calomys, Chinchillula, Eligmodontia, and Andalgalomys. We have not 
noted fenestrae in dorsal sagittal sutures. The size and frequency of occurrence of fenestrae would certainly be less than in the Andinomys and Ctenomys reported here (see also discussion and table of Steppan, 1995: 16, 32).

Comparing males and females (in our two largest samples of Ctenomys), no statistical differences in frequency of occurrence or in mean length or width of fenestrae were detected in either $C$. boliviensis $(\mathrm{n}=52)$ or $C$. opimus $(\mathrm{n}=24)$.

Age (as represented by condyloincisive length of skull) and size of fenestra (length times width of fenestra) in a sample of 52 Ctenomys boliviensis with fenestrae did not show a negative correlation as would be predicted if fenestrae tended to close with increasing age. The correlation coefficient was only 0.24. An analysis of a sample of 24 Ctenomys opimus with fenestrae produced a similar result $(\mathrm{r}=0.04)$.

An analysis of variance of prevalence of fenestrae vs. altitude for Ctenomys from throughout southern South America indicated a significant effect of altitude and prevalence of fenestrae (fig. 8). Although larger sample sizes for all altitudes would be preferable, our analysis shows that for samples of Ctenomys with $\mathrm{n} \geq 4$, there is a significant correlation between the prevalence of fenestrae in Ctenomys and the altitude from which the samples were taken.

The presence of these fenestrae in caviomorph and myomorph rodents and their absence in most of the members of each of these groups indicate that fenestrae have developed independently in several evolutionary lines.

Examination of Steppan's (1993: 194) phylogeny suggests that the occurrence of fenestrae (in at least some adults) has been derived independently in at least three phyllotine lineages (Punomys, Andinomys-Irenomys, and Loxodontomys-Neotomys). Ctenomys demonstrates another independent derivation in a more distantly related family of rodents.

Aside from the untested hypothesis of Rausch et al. (1987) for some possible role in pineal function by which seasonal reproduction of Arctic lemmings of the genus $D i$ crostonyx might be influenced, we have no

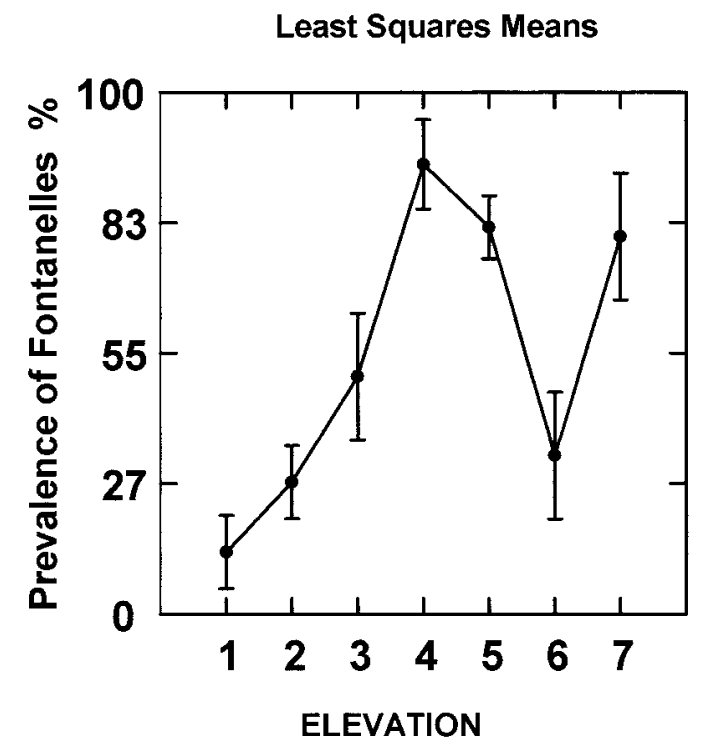

Fig. 8. Results from an analysis of variance of elevation vs. prevalence of fenestrae for only Ctenomys from southern South America for samples that we studied greater than $n=4$. Elevation was coded in $500 \mathrm{~m}$ intervals, with elevation " 1 ", less than $250 \mathrm{~m}$ and elevation 7 greater than or equal to $4000 \mathrm{~m}$. A significant relationship between prevalence of fenestrae and altitude was detected in our analysis.

plausible hypothesis about the function, if any, of the fenestrae of the South American rodents reported here. Rausch et al. (1987) also postulated that "its inheritance involves a dominant autosomal gene with incomplete penetrance." In view of the occurrence of fenestrae in both sexes and with considerable variation as to both occurrence and degree of development, this genetic inference also seems reasonable for the South American rodents. In spite of the variability in both frequency of occurrence and degree of development, there tend to be patterns that seem more likely to involve inheritance than environmental and developmental processes. For example, the fenestrae in Ctenomys opimus (fig. 4) seem slightly more anterior in position than in most of the other species of Ctenomys.

One of us (SLG) noted that several individuals of $C$. opimus at the locality (Bolivia: Oruro; Cruce Ventilla) rested with their heads out of their terrestrial burrows. After 
we noted fenestrae, during other studies, we began to speculate that there may be some relationship among a subterranean habit and high altitude/ high latitude, pineal function, and herbivory. These ideas are interesting, speculative, and not resolvable with present data.

When we first became aware of the occurrence of fenestrae in Andinomys, through previous reports and our own observations, we wondered whether some benefit relating to life at high altitudes might have caused or contributed to their development, in ontogeny or evolution, or both. Two observations reduce the plausibility of such a hypothesis: the absence of fenestrae in many other species that also occur at high altitudes, including closely related species, and the occurrence of fenestrae in certain other species that do not occur at high altitudes.

\section{ACKNOWLEDGMENTS}

Many of the specimens studied were obtained on expeditions financed in large part by grants from the National Science Foundation (BSR 83-16740 and 90-15454 to the American Museum of Natural History; BSR 84-08923 and BSR-86-12329 to the University of New Mexico; and BSR-89-20617, BSR-90-24816, and INT-92-12839 to the University of California, Davis). A NATO grant (CRG-920612) to Scott L. Gardner is also acknowledged. Collaboration by students and other colleagues from Bolivian institutions in the fieldwork is acknowledged gratefully. We thank, also, the librarians and others at the Southwest Foundation for Biomedical Research, in San Antonio, Texas, for use of their facilities on a visit there. The comments of several reviewers have been helpful, but the authors bear the final responsibility for content and organization.

\section{REFERENCES}

Altuna, C. A., and E. P. Lessa

1985. Penial morphology in Uruguayan species of Ctenomys (Rodentia: Octodontidae). J. Mammal. 66: 483-488.

Anderson, S.

1997. Mammals of Bolivia, taxonomy and distribution. Bull. Am. Mus. Nat. Hist. 231: $652 \mathrm{pp}$.
Anderson, S., and T. L. Yates

2000. A new genus and species of phyllotine rodent from Bolivia. J. Mammal. 81: $18-36$.

Anderson, S., T. L. Yates, and J. A. Cook

1987. Notes on Bolivian mammals 4: The genus Ctenomys (Rodentia: Ctenomyidae) in the eastern lowlands. Am. Mus. Novitates 2891: 20 pp.

Berry, R. J., and A. G. Searle

1963. Epigenetic polymorphism of the rodent skeleton. Proc. Zool. Soc. London 140: 577-615.

Braun, J. K.

1993. Systematic relationships of the tribe Phyllotini (Muridae: Sigmodontinae) of South America. Oklahoma Mus. Nat. Hist., Spec. Publ., 50 pp.

Cook, J. A., S. Anderson, and T. L. Yates

1990. Notes on Bolivian mammals 6: The genus Ctenomys (Rodentia, Ctenomyidae) in the highlands. Am. Mus. Novitates 2980: 27pp.

Duc, G., and R. H. Largo

1986. Anterior fontanel: size and closure in term and preterm infants. Pediatrics 78: 904-908.

Genoways, H. H.

1973. Systematics and evolutionary relationships of spiny pocket mice, genus Liomys. Mus. Texas Tech. Univ. Spec. Publ. 5: 368 pp.

Girdany, B. R., and E. Blank

1965. Anterior fontanel bones. Am. J. Roentgenol. Radium Ther. Nucl. Med. 95: 148-153.

Hershkovitz, P. H.

1962. Evolution of neotropical cricetine rodents (Muridae) with special reference to the phyllotine group. Fieldiana Zool. 46: $1-524$.

Hill, J. E.

1935. The cranial foramina in rodents. J. Mammal. 36: 121-129.

Hinton, M. A. C.

1926. Monograph of the voles and lemmings (Microtinae) living and extinct. Vol. 1. London: British Museum, xvi +488 pp. +15 pls.

Kadanoff, D., and S. Mutafov

1963. Typisch lokalisierte Zwischenfontanellennahtknochen. C. R. Acad. Bulg. Sci. 16: 673-676.

Langguth, A., and A. Abella

1970. Las especies uruguayas del genero Ctenomys (Rodentia-Octodontidae). Comun. Zool. Mus. Hist. Nat. Montev. 129: $1-20+3$ tables. 
Manville, R. H.

1959. Bregmatic bones in North American Lynx. Science 130: 1254.

Olds, N., and S. Anderson

1990. A diagnosis of the tribe Phyllotini (Rodentia, Muridae). In K. H. Redford and J. F. Eisenberg (eds.), Advances in Neotropical mammalogy: 55-74. Gainesville FL: Sandhill Crane Press, ix +614 pp.

Osgood, W. H.

1947. Cricetine rodents allied to Phyllotis. J. Mammal. 28: 165-174.

Pacheco, V., and J. L. Patton

1995. A new species of the puna mouse, genus Punomys Osgood, 1943 (Muridae, Sigmodontinae) from the southeastern Andes of Perú. Z. Säugetierkd. 60: 8596.

Pratt, L. W.

1942. Bregmatic fontanelle bones in the genus Lynx. J. Mammal. 23: 411-416.

Rausch, R. L., V. R. Rausch, and J. W. Lindsay

1987. Fenestrated cranium in varying lemmings, Dicrostonyx spp. (Rodentia: Arvicolidae), in the Nearctic. Zool. Anz. 218: $170-176$.
Soria, M. F.

1962. Hueso fontanelar bregmatico y canino supernumerario en un "Hylobates." Comun. Mus. Argent. Cienc. Nat. "Bernardino Rivadavia" Inst. Nac. InSteppan, S. vestig. Cienc. Nat. Zool. 3: 217-232.

1993. Phylogenetic relationships among the Phyllotini (Rodentia: Sigmodontinae) using morphological characters. J. Mamm. Evol. 1: 187-213.

1995. Revision of the Tribe Phyllotini (Rodentia: Sigmodontinae), with a phylogenetic hypothesis for the Sigmodontinae. Fieldiana Zool. New Ser. 80(1464): Svi + 112 pp.

Truslove, G. M.

1952. Genetic studies on the skeleton of the mouse V. 'interfrontal' and 'parted frontals'. J. Genet. 51: 115-122.

Wahlert, J. H., S. L. Sawitzke, and M. E. Holden

1993. Cranial anatomy and relationships of dormice (Rodentia, Myoxidae). Am. Mus. Novitates 3061: 32 pp.

Wilson, D. E., and D. M. Reeder

1993. Mammal species of the world, a taxonomic and geographic reference. Washington DC: Smithsonian Institution Press, xviii +1206 pp. 
Recent issues of the Novitates may be purchased from the Museum. Lists of back issues of the Novitates and Bulletin published during the last five years are available at World Wide Web site http://nimidi.amnh.org. Or address mail orders to: American Museum of Natural History Library, Central Park West at 79th St., New York, NY 10024. TEL: (212) 769-5545. FAX: (212) 7695009. E-MAIL: scipubs@amnh.org

(-) This paper meets the requirements of ANSI/NISO Z39.48-1992 (Permanence of Paper). 